\title{
The differentiation between solitary pulmonary inflammatory lesion and solitary cancer using gemstone spectral imaging (GSI): the correlation with lesion size
}

\section{Liuhong Zhu}

Radiology Department, Xiamen Branch, Zhongshan Hospital, Fudan University

\section{Funan Wang}

Radiology department, Xiamen Branch, Zhongshan Hospital, Fudan University

\section{Yanwei Wang}

Radiology Department, the Second Affiliated Hospital of Xiamen Medical College

\section{Qihua Cheng}

Radiology Department, the Second Affiliated Hospital of Xiamen Medical College Jianjun Zhou ( zsxmfskz@163.com)

Zhongshan Hospital Fudan University

\section{Research}

Keywords: Gemstone spectral CT imaging (GSI), normalized lodine concentration, slope of spectral curve, solitary lung inflammatory, solitary lung cancer

Posted Date: November 2nd, 2020

DOI: https://doi.org/10.21203/rs.3.rs-97871/v1

License: (c) (i) This work is licensed under a Creative Commons Attribution 4.0 International License.

Read Full License 


\section{Abstract}

Background: There were still nonnegligible overlaps between lung inflammatory and malignant lesions in morphologic appearance and enhancement pattern using conventional computed tomography (CT) especially when the lesion size was smaller than $3 \mathrm{~cm}$, which made misdiagnosis often happen in clinical practice. The study was to verify whether spectral CT parameters can differentiate solitary lung cancer from solitary inflammatory lesions or not, and to find the correlation between GSI parameters and lesion size.

Methods: 102 patients with solitary inflammatory or lung cancer lesions underwent enhanced CT scans with GSI mode. While total of 78 ROIs (region of interest) were finally collected and divided into inflammatory group (group I: $\leq 3 \mathrm{~cm}, I A ;>3 \mathrm{~cm}, \mathrm{IB}$ ) and cancer group (group II: $\leq 3 \mathrm{~cm}, \mathrm{IIA} ;>3 \mathrm{~cm}, \mathrm{IIB}$ ) according to their maximum diameter $\left(D_{\text {max }}\right)$. CT values measured on $40 \mathrm{keV}$ and $70 \mathrm{keV}$ monochromatic images $\left(\mathrm{HU}_{40 \mathrm{kev}}, \mathrm{HU}_{70 \mathrm{kev}}\right)$, effective atomic number $\left(\mathrm{Z}_{\mathrm{eff}}\right)$, iodine concentration (IC), normalized IC (NIC) and slopes of spectral curve $\left(\lambda_{30}, \lambda_{40}\right)$ were calculated. Intergroup and intragroup comparisons were made using Mann-Whitney $U$ test, and receiver operating characteristic curve (ROC) analysis were done. Correlation analysis was used to find the relationship between $\mathrm{D}_{\max }$ and GSI parameters.

Results: NIC and $\lambda_{30}$ under venous phase could distinguish general solitary inflammatory from cancer group. No significant correlation was found between GSI parameters and $D_{\max }$ in inflammatory group, while negative correlations were found between them in cancer group. The GSI parameters (except $\mathrm{HU}_{70 \mathrm{kev}}$ ) of group IIA were significantly higher than those of group IIB. When $\mathrm{D}_{\max }$ was larger than $3 \mathrm{~cm}$, there were significant differences between solitary inflammatory group and cancer group in $\mathrm{HU}_{40 \mathrm{kev}}$, IC, $\mathrm{NIC}, \lambda_{30}$ and $\lambda_{40}$, under both AP and VP, while the AUC for $\lambda_{30}$ under VP was largest, and the corresponding sensitivity and specificity were $96.32 \%$ and $85.71 \%$ respectively. However, only the $\mathrm{HU}_{40 \mathrm{kev}}$ and $\mathrm{HU}_{70 \mathrm{kev}}$ under arterial phase of IIA were significantly higher than those of IA.

Conclusions: Most of quantitative parameters of GSI can contribute to the differentiation between solitary lung cancer from solitary inflammatory lesions when $D_{\max }$ is larger than $3 \mathrm{~cm}$, while only few parameters are meaningful when $D_{\max }$ is smaller than $3 \mathrm{~cm}$.

\section{Background}

Up to 2.1 million new cases of lung cancer occurred globally in 2018, ranking first among all cancer types. Although the survival rates for all cancers have improved in recent years, lung cancer survival remains at a relatively low level, which in men was about $16.8 \%$ and $25.1 \%$ in women [1-3]. Early surgery and chemotherapy, which were based on accurate diagnosis, have been shown to be effective treatment techniques in most patients with lung cancer. However, the misdiagnosis rate of solitary pulmonary lesions was relatively high in clinical practice, and remained a hot topic among researchers. 
Evaluation of the solitary pulmonary lesions remains a challenge in clinical. Among all imaging examination tools, conventional contrast-enhanced CT scan is still the most important one for the patient with solitary pulmonary lesion [4]. It can offer the morphological signs, inner densities and enhancement patterns to characterize pulmonary lesions. However, there is considerable overlap between inflammatory and malignant masses in morphologic appearance and enhancement pattern, especially when the size of lesion is less than $3 \mathrm{~cm}$, making it difficult to produce an accurate diagnosis in clinical practice.

With the rapid development of dual-energy spectral CT imaging, the researchers turned to explore its potential in the diagnosis of solitary pulmonary lesions. As one of dual-energy spectral CT imaging techniques [5], GSI was based on rapid switching between high and low voltage (80kVp and $140 \mathrm{kVp}$ ) during a single rotation of the tube. It can acquire multiple parameters, such as monochromatic spectral images at energy levels ranging from 40 to $140 \mathrm{keV}$, material decomposition images, effective atomic number and spectral HU curve [6, 7]. Specially, iodine concentration measured on iodine-enhanced images, which is considered to be comparable to the real value of enhancement, could reflect the blood supply of pulmonary lesions, and is essential for differential diagnosis [8, 9]. The spectral CT imaging has been applied to multiple studies, such as non-small cell lung cancer (NSCLC) subtype differentiation $[9,10]$, gastric cancer evaluation $[11,12]$ and hepatocellular cancer differentiation [13-15], evaluation of lymph nodes preoperatively [16] and differentiation between benign and malignant solitary pulmonary nodules (SPNs) [17], etc.. Several researchers reported that spectral CT imaging with quantitative parameters may be useful in the differentiation of solitary lung cancer from solitary inflammatory lesions [18-19], however, they haven't taken the lesion size into account. Therefore, the aim of our study was to verify whether spectral CT parameters under GSI mode can differentiate solitary lung cancer from solitary inflammatory lesions, and clarify the correlation between GSI parameters and the lesion size.

\section{Methods}

\section{Study population and groups}

This prospective study was reviewed and approved by the Medical Ethics Committee of the Second Affiliated Hospital of Xiamen Medical College (approval No. 2016011) and written informed consent was obtained from all subjects prior to the examination. A total of 102 patients with suspected solitary pulmonary lesions were enrolled in our study during past eight months.

Patients were selected according to the following inclusion criteria: (a) presence of a solitary pulmonary lesion, (b) no contraindications to the administration of iodinated contrast material, and (c) were able to finish the procedures cooperatively. They were underwent dual-phase CT scanning under GSI mode. And seventeen patients were excluded due to : (a) the lesion was combined with cavitation and significant calcification $(n=8)$, (b) absence or inadequate pathologic diagnosis $(n=9)$, (c) unsatisfactory image quality because of artifacts caused by contrast material $(n=3)$, and (d) ground glass nodules and /or nonsolid nodules $(n=4)$. Thus, 78 patients ( 49 men, 28 women, average age, $59.1 \pm 7.3$ years) were finally included in our study. 
Seventy-eight lesions in all patients were divided into two groups based on the pathologic results. Lung cancer group $(n=47)$ was composed of adenocancer $(n=28)$ and squamous cell cancer $(n=19)$. Lung inflammatory group $(n=31)$ was composed of granuloma $(n=9)$ and pneumonia $(n=22)$. Taking 3 centimeter as the cutoff value for the maximum diameter of lesions, the above each group can be divided into two subgroups respectively (Table 1 ).

\section{Table 1. Characteristics of lesions}

\begin{tabular}{|c|c|c|}
\hline Diagnosis & $D_{\max } \leq 3 \mathrm{~cm}$ & $\mathrm{D}_{\max }>3 \mathrm{~cm}$ \\
\hline Lung inflammatory & Group IA (n=17, 55\%, & Group IB (n=14, 45\%, \\
\hline \multirow[t]{3}{*}{ (Group I, n=31) } & $\left.\overline{D_{\max }}: 1.87 \pm 0.61 \mathrm{~cm}\right)$ & $\left.\overline{D_{\max }}: 4.83 \pm 1.12 \mathrm{~cm}\right)$ \\
\hline & Granuloma $(n=11)$ & Granuloma $(n=10)$ \\
\hline & Pneumonia $(n=6)$ & Pneumonia $(n=4)$ \\
\hline Lung cancer & Group IIA ( $n=20,43 \%$, & Group IIB (n=27, 57\%, \\
\hline \multirow[t]{3}{*}{ (Group II, n=47) } & $\left.\overline{D_{\max }}: 2.13 \pm 0.28 \mathrm{~cm}\right)$ & $\left.\overline{D_{\max }}: 5.31 \pm 1.55 \mathrm{~cm}\right)$ \\
\hline & Adenocancer $(n=12)$ & Adenocancer $(n=16)$ \\
\hline & Squamous cell cancer $(n=8)$ & Squamous cell cancer $(n=11)$ \\
\hline
\end{tabular}

Note: $\overline{D_{\max }}$ means the average value of $\mathrm{D}_{\max }$ of a specific group.

\section{Imaging techniques}

Computed tomography examinations were performed using two-phase enhanced CT scanning on a spectral CT scanner (GE Discovery 750HD CT ; GE Healthcare, Milwaukee, WI, USA) under GSI mode. Patients were injected with the given volume $(1.1 \mathrm{ml} / \mathrm{kg}$ of body weight) of nonionic contrast media named loversol (320 mg l/ml, GE healthcare) through venous access. The injection flow rate was 3$3.5 \mathrm{ml} / \mathrm{s}$, followed by $30 \mathrm{ml}$ saline with same rate. When the net CT value of descending aorta increased by $100 \mathrm{HU}$, the arterial phase (AP) scanning was triggered (about $22 \sim 28 \mathrm{~s}$ after the start of contrast medium injection). The venous phase (VP) scanning was $40 \mathrm{~s}$ delay after the AP. The GSI scanning parameters were: scan range including the entire chest, helical tube rotation time 0.8 seconds, helical pitch 1.375:1, tube current of $260 \mathrm{~mA}$, slice thickness of $1.25 \mathrm{~mm}$ and spacing of $1.25 \mathrm{~mm}$. The CT dose index volume (CTDI ${ }_{\text {vol }}$ ) for each phase under GSI mode was $7.37 \mathrm{mGy}$. A dataset of monochromatic images at energies ranging from 40 to $140 \mathrm{keV}$ was generated, which can be analyzed with GSI Volume Viewer software package at AW4.6 workstation (GE Healthcare).

\section{Images analysis}

Two radiologists (YW.W and QH.C with 7 and 22 years of experience in chest CT diagnosis respectively), who were blinded to pathologic diagnosis, interpreted and analyzed the images independent of each 
other.

(a). Firstly, raw data containing both AP and VP of each patient were loaded using GSI Volume Viewer software simultaneously to ensure the size, shape and location of regions of interest (ROls) afterwards were the same on both AP and VP to the greatest extent.

(b). After reviewing the lesion manifestations, three ROls were placed at the upper, middle (maximum section) and lower slices of the lesion respectively. The ROls were outlined as large as possible on the condition of avoiding necrosis, vessels and bronchi. And the average values of the three represented the measurement.

(c). Outline a round ROI on descending aorta at the carina level.

(d). Measured the maximum diameter $\left(D_{\max }\right)$ of each lesion to represent the lesion size.

For each ROI, CT values measured on $40 \mathrm{keV}$ and $70 \mathrm{keV}$ monochromatic images $\left(\mathrm{HU}_{40 \mathrm{kev}}, \mathrm{HU}_{70 \mathrm{kev}}\right)$, effective atomic number ( $\left.Z_{\text {eff }}\right)$ and iodine concentration (IC) measured on iodine/water based material decomposition image under two phases were obtained. Normalized iodine concentration (NIC) and slopes of the spectral HU curve $\left(\lambda_{30}, \lambda_{40}\right)$ under two phases were calculated. The NIC was defined as the $\mathrm{IC}$ ratio between lesion and descending aorta $\left(\mathrm{NIC}=\mathrm{IC}_{\text {leison }} / \mathrm{IC}_{\mathrm{aortic}}\right)$. The $\lambda_{30}$ and $\lambda_{40}$ were calculated as $\mid \mathrm{HU}_{40 \mathrm{keV}}-\mathrm{HU}_{70 \mathrm{kev}} / 30$, and $\mid \mathrm{HU}_{40 \mathrm{keV}}-\mathrm{HU}_{80 \mathrm{kev}} / / 40$ respectively. Above seven parameters of each phase were used in our study.

\section{Statistical analysis}

The parameters were expressed as mean \pm standard deviation. All the data were test for the normality before two sample t-test comparisons. When the data did not meet the normality, Mann-Whitney $U$ test was used to statistically compare these parameters between groups. Group I and II were compared to find out whether the GSI parameters were useful in their differentiation diagnosis. To test the influence of lesion size to the GSI parameters, group IA and IB, IIA and IIB were compared, and the correlation between $D_{\max }$ and GSI parameters were done. Also, we compared group IA and IIA, IB and IIB to verify the performance of GSI parameters in the distinguishing lung cancer and lung inflammatory when the lesion size was lower and higher than $3 \mathrm{~cm}$ respectively. ROC analysis about the performance of these parameters were done. $\mathrm{P}$ value $<0.05$ was considered to indicate a significant difference. All statistical analyses were performed using SPSS (Version 25.0; Chicago, IL, USA) and Prism (Version 8.3; Graphpad Software; San Diego, CA, USA) software.

\section{Results}

\section{General comparison}

The solitary lung inflammatory group and lung cancer group were compared in Table 2 . There were no significant differences in $\mathrm{HU}_{40 \mathrm{kev}}, \mathrm{HU}_{70 \mathrm{kev}}, \mathrm{Z}_{\text {eff }}$ at both AP and VP between general solitary inflammatory 
group and lung cancer group. While the IC, NIC $\lambda_{30}, \lambda_{40}$ under VP and $\lambda_{30}$ under AP of lung cancer group were significantly lower than those of inflammatory group. The ROC curves for predicting solitary inflammatory from cancer based on these indices were compared (Fig. 1), and the AUC of $\lambda_{30}$ under VP were highest $(A \cup C=0.74)$.

Table 2

The GSI parameters for differentiating general solitary lung inflammatory and lung cancer lesions

\begin{tabular}{|c|c|c|c|c|c|c|c|c|}
\hline \multicolumn{2}{|c|}{ Group } & \multirow{2}{*}{$\begin{array}{l}\mathrm{HU}_{40 \mathrm{kev}} \\
(\mathrm{HU})\end{array}$} & \multirow{2}{*}{$\begin{array}{l}\mathrm{HU}_{70 \mathrm{kev}} \\
(\mathrm{HU}) \\
49.42 \pm \\
10.94\end{array}$} & \multirow{2}{*}{$\begin{array}{l}Z_{\text {eff }} \\
8.22 \pm \\
0.3\end{array}$} & \multirow{2}{*}{$\begin{array}{l}\text { IC } \\
(* 100 \mu \mathrm{g} / \mathrm{ml}) \\
10.49 \pm 5.38\end{array}$} & \multirow{2}{*}{$\begin{array}{l}\text { NIC } \\
0.11 \pm \\
0.05\end{array}$} & \multirow{2}{*}{$\begin{array}{l}\lambda_{30} \\
1.89 \pm \\
1.07\end{array}$} & \multirow{2}{*}{$\begin{array}{l}\lambda_{40} \\
1.67 \pm \\
0.87\end{array}$} \\
\hline AP & Inflammatory & & & & & & & \\
\hline & Cancer & $\begin{array}{l}104.24 \pm \\
33.76\end{array}$ & $\begin{array}{l}53.53 \pm \\
12.96\end{array}$ & $\begin{array}{l}8.14 \pm \\
0.22\end{array}$ & $9.18 \pm 3.87$ & $\begin{array}{l}0.10 \pm \\
0.03\end{array}$ & $\begin{array}{l}1.34 \pm \\
0.53\end{array}$ & $\begin{array}{l}1.46 \pm \\
0.59\end{array}$ \\
\hline & $P$ value & 0.834 & 0.122 & 0.279 & 0.385 & 0.294 & $0.030 *$ & 0.377 \\
\hline & $A U C$ & / & / & I & / & / & 0.65 & I \\
\hline \multirow[t]{4}{*}{ VP } & Inflammatory & $\begin{array}{l}123.46 \pm \\
43.10\end{array}$ & $\begin{array}{l}55.16 \pm \\
22.53\end{array}$ & $\begin{array}{l}8.28 \pm \\
0.29\end{array}$ & $12.47 \pm 4.88$ & $\begin{array}{l}0.48 \pm \\
0.24\end{array}$ & $\begin{array}{l}2.13 \pm \\
0.85\end{array}$ & $\begin{array}{l}1.97 \pm \\
0.72\end{array}$ \\
\hline & Cancer & $\begin{array}{l}114.38 \pm \\
30.26\end{array}$ & $\begin{array}{l}57.24 \pm \\
10.99\end{array}$ & $\begin{array}{l}8.17 \pm \\
0.20\end{array}$ & $10.16 \pm 3.33$ & $\begin{array}{l}0.33 \pm \\
0.10\end{array}$ & $\begin{array}{l}1.45 \pm \\
0.49\end{array}$ & $\begin{array}{l}1.59 \pm \\
0.54\end{array}$ \\
\hline & $P$ value & 0.242 & 0.523 & 0.09 & $0.035^{*}$ & $0.011^{*}$ & $\dot{0} 0.01 *$ & $0.012^{*}$ \\
\hline & $A U C$ & I & I & I & 0.64 & 0.67 & 0.74 & 0.67 \\
\hline \multicolumn{9}{|c|}{$\begin{array}{l}\text { Note: } A P \text {, arterial phase; } V P \text {, venous phase; } H U 4 O_{k e v} / H U 7 O_{k e v} \text {, the } C T \text { number on the } 40 \mathrm{kev} / 70 \mathrm{kev} \\
\text { monochromatic image; } Z_{\text {eff }} \text { effective atomic number; } I C \text {, iodine concentration; } N I C \text {, normalized iodine } \\
\text { concentration; } \lambda_{30} / \lambda_{40} \text {, the slope of spectral curve; * means } p<0.05 \text {. }\end{array}$} \\
\hline
\end{tabular}

\section{The intra-group comparison of GSI parameters and correlation analysis between $D_{\max }$ and GSI parameter}

The inflammatory group (group I) was divided into two subgroups (group IA: $D_{\max } \leq 3 \mathrm{~cm}$ ) and (group IB: $D_{\max }>3 \mathrm{~cm}$ ). No significant differences were found between the GSI parameters of group IA and IB under both AP and VP (Table 3). The Pearson correlation between $D_{\max }$ and GSI parameters of solitary inflammatory group were also done. No significant correlation between $D_{\max }$ and any GSI parameters were found ( $p$ (two tailed) >0.05) under both AP and VP, and Fig. 2 showed the scatter chart of GSI parameters plotted with $D_{\max }$ under VP. 
Table 3

The difference between subgroup IA $\left(D_{\max } \leq 3 \mathrm{~cm}\right)$ and subgroup IB $\left(D_{\max }>3 \mathrm{~cm}\right)$ in $\mathrm{GSI}$ parameters of solitary lung inflammatory

\begin{tabular}{|c|c|c|c|c|c|c|c|c|}
\hline \multicolumn{2}{|c|}{ Group } & \multirow{2}{*}{$\begin{array}{l}\mathrm{HU}_{40 \mathrm{kev}} \\
(\mathrm{HU}) \\
94.81 \pm \\
41.06\end{array}$} & \multirow{2}{*}{$\begin{array}{l}\mathrm{HU}_{70 \mathrm{kev}} \\
(\mathrm{HU})\end{array}$} & \multirow{2}{*}{$\begin{array}{l}Z_{\text {eff }} \\
\\
8.19 \pm \\
0.31\end{array}$} & \multirow{2}{*}{$\begin{array}{l}\text { IC } \\
(* 100 \mu \mathrm{g} / \mathrm{ml}) \\
9.67 \pm 4.95\end{array}$} & \multirow{2}{*}{$\begin{array}{l}\text { NIC } \\
0.10 \pm \\
0.05\end{array}$} & \multirow{2}{*}{$\begin{array}{l}\lambda_{30} \\
\\
1.79 \pm \\
0.99\end{array}$} & \multirow{2}{*}{$\begin{array}{l}\lambda_{40} \\
1.51 \pm \\
0.77\end{array}$} \\
\hline $\mathrm{AP}$ & $\begin{array}{l}I A(n= \\
17)\end{array}$ & & & & & & & \\
\hline & $\begin{array}{l}\text { IB }(n= \\
14)\end{array}$ & $\begin{array}{l}124.81 \pm \\
42.77\end{array}$ & $\begin{array}{l}52.78 \pm \\
10.52\end{array}$ & $\begin{array}{l}8.26 \pm \\
0.33\end{array}$ & $11.48 \pm 5.88$ & $\begin{array}{l}0.13 \pm \\
0.05\end{array}$ & $\begin{array}{l}2.01 \pm \\
1.19\end{array}$ & $\begin{array}{l}1.88 \pm \\
0.97\end{array}$ \\
\hline & $\begin{array}{l}P \\
\text { value }\end{array}$ & 0.53 & 0.059 & 0.92 & 0.625 & 0.297 & 0.681 & 0.336 \\
\hline \multirow[t]{3}{*}{ VP } & $\begin{array}{l}\text { IA }(n= \\
17)\end{array}$ & $\begin{array}{l}113.44 \pm \\
43.70\end{array}$ & $\begin{array}{l}50.50 \pm \\
27.75\end{array}$ & $\begin{array}{l}8.28 \pm \\
0.24\end{array}$ & $11.42 \pm 3.96$ & $\begin{array}{l}0.40 \pm \\
0.16\end{array}$ & $\begin{array}{l}1.91 \pm \\
0.78\end{array}$ & $\begin{array}{l}1.81 \pm \\
0.63\end{array}$ \\
\hline & $\begin{array}{l}\mathrm{IB}(\mathrm{n}= \\
14)\end{array}$ & $\begin{array}{l}135.62 \pm \\
40.58\end{array}$ & $\begin{array}{l}60.82 \pm \\
12.68\end{array}$ & $\begin{array}{l}8.28 \pm \\
0.36\end{array}$ & $13.76 \pm 5.68$ & $\begin{array}{l}0.59 \pm \\
0.29\end{array}$ & $\begin{array}{l}2.39 \pm \\
0.88\end{array}$ & $\begin{array}{l}2.16 \pm \\
0.79\end{array}$ \\
\hline & $\begin{array}{l}P \\
\text { value }\end{array}$ & 0.100 & 0.161 & 0.860 & 0.186 & 0.064 & 0.084 & 0.100 \\
\hline
\end{tabular}

For the cancer group (group II), it was also divided into two subgroups (group IIA: $D_{\max } \leq 3 \mathrm{~cm}$ ) and (group IIB: $D_{\max }>3 \mathrm{~cm}$ ). Significant differences were found between GSI parameters of group IIA andI IIB under both AP and VP except parameter $\mathrm{HU}_{70 \mathrm{kev}}$ (Table 4). The Pearson correlation between $\mathrm{D}_{\max }$ and $\mathrm{GSI}$ parameters of solitary cancer group were also done. Significantly negative correlation between $D_{\max }$ and any GSI parameters (except $\mathrm{HU}_{70 \mathrm{kev}}$ ) were found ( $\mathrm{p}$ (two tailed) $<0.05$ ) under both AP and VP, and Fig. 3 showed the scatter chart of GSI parameters changed with $D_{\max }$ under VP. 
Table 4

The difference between subgroup IIA $(\leq 3 \mathrm{~cm})$ and subgroup IIB $(>3 \mathrm{~cm})$ in GSI parameters of solitary lung cancer

\begin{tabular}{|c|c|c|c|c|c|c|c|c|}
\hline \multicolumn{2}{|c|}{ Group } & \multirow{2}{*}{$\begin{array}{l}\mathrm{HU}_{40 \mathrm{kev}} \\
(\mathrm{HU})\end{array}$} & \multirow{2}{*}{$\begin{array}{l}\mathrm{HU}_{70 \mathrm{kev}} \\
(\mathrm{HU}) \\
56.60 \pm \\
12.17\end{array}$} & \multirow{2}{*}{$\begin{array}{l}Z_{\text {eff }} \\
8.25 \pm \\
0.22\end{array}$} & \multirow{2}{*}{$\begin{array}{l}\text { IC } \\
(* 100 \mu \mathrm{g} / \mathrm{ml}) \\
10.97 \pm 3.94\end{array}$} & \multirow{2}{*}{$\begin{array}{l}\text { NIC } \\
0.11 \pm \\
0.03\end{array}$} & \multirow{2}{*}{$\begin{array}{l}\lambda_{30} \\
1.57 \pm \\
0.56\end{array}$} & \multirow{2}{*}{$\begin{array}{l}\lambda_{40} \\
1.73 \pm \\
0.61\end{array}$} \\
\hline AP & $\begin{array}{l}\text { IIA }(n= \\
20)\end{array}$ & & & & & & & \\
\hline & $\begin{array}{l}\text { IIB }(n= \\
27)\end{array}$ & $\begin{array}{l}92.29 \pm \\
31.55\end{array}$ & $\begin{array}{l}51.26 \pm \\
13.27\end{array}$ & $\begin{array}{l}8.06 \pm \\
0.19\end{array}$ & $7.86 \pm 3.29$ & $\begin{array}{l}0.09 \pm \\
0.03\end{array}$ & $\begin{array}{l}1.16 \pm \\
0.44\end{array}$ & $\begin{array}{l}1.26 \pm \\
0.49\end{array}$ \\
\hline & $P$ value & $0.003^{*}$ & 0.149 & $0.002 *$ & $0.009 *$ & $0.022^{*}$ & $0.011 *$ & $0.009 *$ \\
\hline \multirow[t]{3}{*}{ VP } & $\begin{array}{l}\text { IIA }(n= \\
20)\end{array}$ & $\begin{array}{l}133.07 \pm \\
25.57\end{array}$ & $\begin{array}{l}59.58 \pm \\
7.66\end{array}$ & $\begin{array}{l}8.27 \pm \\
0.21\end{array}$ & $12.13 \pm 3.30$ & $\begin{array}{l}0.39 \pm \\
0.09\end{array}$ & $\begin{array}{l}1.76 \pm \\
0.48\end{array}$ & $\begin{array}{l}1.94 \pm \\
0.53\end{array}$ \\
\hline & $\begin{array}{l}\text { IIB }(n= \\
27)\end{array}$ & $\begin{array}{l}100.54 \pm \\
25.97\end{array}$ & $\begin{array}{l}54.02 \pm \\
10.93\end{array}$ & $\begin{array}{l}8.09 \pm \\
0.16\end{array}$ & $8.70 \pm 2.55$ & $\begin{array}{l}0.29 \pm \\
0.08\end{array}$ & $\begin{array}{l}1.22 \pm \\
0.35\end{array}$ & $\begin{array}{l}1.33 \pm \\
0.39\end{array}$ \\
\hline & $P$ value & $<0.001 *$ & 0.093 & 0.004* & $<0.001 *$ & <. & $<.001 *$ & <. \\
\hline
\end{tabular}

\section{The inter-group comparisons between subgroup IA and IB, IIA and IIB under two phases}

Significant differences can be found in $\mathrm{HU}_{40 \mathrm{kev}}$ and $\mathrm{HU} \mathrm{O}_{\mathrm{kev}}$ under AP between lung inflammatory and cancer when the $D_{\max }$ of a solitary lesion was no larger than $3 \mathrm{~cm}$ (Table 5, Fig. 4, Fig. 5). The AUC, sensitivity and specificity were $0.72,95.0 \%$ and $58.8 \%$ for $\mathrm{HU}_{40 \mathrm{kev}}$ under $\mathrm{AP}$, and $0.74,75.0 \%, 82.4 \%$ for $H U 70_{\text {kev }}$ under AP. When the $D_{\text {max }}$ of a solitary lesion was larger than $3 \mathrm{~cm}$, the $\mathrm{HU}_{40 \mathrm{kev}}, \mathrm{IC}, \mathrm{NIC}, \lambda_{30}$ and $\lambda_{40}$ under both AP and VP of the inflammatory group were significantly higher than those of the cancer group (Table 5, Fig. 4, Fig. 6). The ROC analysis (Fig. 7) showed that the AUC, sensitivity and specificity for $\lambda_{30}$ under VP performed best (AUC 0.90, sensitivity $96.32 \%$ and specificity $85.71 \%$ ). 
Table 5

The comparison of GSI parameters between group IA and IB, group IIA and IIB

\begin{tabular}{|c|c|c|c|c|c|c|c|c|}
\hline \multicolumn{2}{|c|}{ Group } & \multirow{2}{*}{$\begin{array}{l}\mathrm{HU}_{40 \mathrm{kev}} \\
(\mathrm{HU}) \\
90.69 \pm \\
43.25\end{array}$} & \multirow{2}{*}{$\begin{array}{l}\mathrm{HU}_{70 \mathrm{kev}} \\
(\mathrm{HU}) \\
46.66 \pm \\
10.81\end{array}$} & \multirow{2}{*}{$\begin{array}{l}Z_{\text {eff }} \\
8.19 \pm \\
0.31\end{array}$} & \multirow{2}{*}{$\begin{array}{l}\text { IC } \\
(* 100 \mu \mathrm{g} / \mathrm{ml})\end{array}$} & \multirow{2}{*}{$\begin{array}{l}\text { NIC } \\
0.10 \pm \\
0.05\end{array}$} & \multirow{2}{*}{$\begin{array}{l}\lambda_{30} \\
1.79 \pm \\
0.99\end{array}$} & \multirow{2}{*}{$\begin{array}{l}\lambda_{40} \\
1.51 \pm \\
0.77\end{array}$} \\
\hline $\mathrm{AP}$ & $\begin{array}{l}\text { IA }(n= \\
17)\end{array}$ & & & & & & & \\
\hline & $\begin{array}{l}\| A(n= \\
20)\end{array}$ & $\begin{array}{l}120.38 \pm \\
30.32\end{array}$ & $\begin{array}{l}56.60 \pm \\
12.17\end{array}$ & $\begin{array}{l}8.25 \pm \\
0.22\end{array}$ & $10.97 \pm 3.94$ & $\begin{array}{l}0.11 \pm \\
0.03\end{array}$ & $\begin{array}{l}1.57 \pm \\
0.56\end{array}$ & $\begin{array}{l}1.73 \pm \\
0.61\end{array}$ \\
\hline & $P$ value & $0.026^{*}$ & $0.011^{*}$ & 0.517 & 0.326 & 0.557 & 0.752 & 0.297 \\
\hline & $A U C$ & 0.71 & 0.74 & I & I & I & I & I \\
\hline & $\begin{array}{l}\text { IB }(n= \\
14)\end{array}$ & $\begin{array}{l}124.81 \pm \\
42.77\end{array}$ & $\begin{array}{l}52.78 \pm \\
10.52\end{array}$ & $\begin{array}{l}8.26 \pm \\
0.33\end{array}$ & $11.48 \pm 5.88$ & $\begin{array}{l}0.13 \pm \\
0.05\end{array}$ & $\begin{array}{l}2.01 \pm \\
1.19\end{array}$ & $\begin{array}{l}1.88 \pm \\
0.97\end{array}$ \\
\hline & $\begin{array}{l}\text { IIB }(n= \\
27)\end{array}$ & $\begin{array}{l}92.29 \pm \\
31.55\end{array}$ & $\begin{array}{l}51.26 \pm \\
13.27\end{array}$ & $\begin{array}{l}8.06 \pm \\
0.19\end{array}$ & $7.86 \pm 3.29$ & $\begin{array}{l}0.09 \pm \\
0.03\end{array}$ & $\begin{array}{l}1.16 \pm \\
0.44\end{array}$ & $\begin{array}{l}1.26 \pm \\
0.49\end{array}$ \\
\hline & $P$ value & $0.014^{*}$ & 0.734 & $0.037^{*}$ & $0.042^{*}$ & $0.045^{\star}$ & $0.007^{*}$ & $0.026^{*}$ \\
\hline & $A U C$ & 0.74 & I & 0.70 & 0.70 & 0.69 & 0.75 & 0.71 \\
\hline \multirow[t]{7}{*}{ VP } & $\begin{array}{l}\text { IA }(n= \\
17)\end{array}$ & $\begin{array}{l}113.44 \pm \\
43.70\end{array}$ & $\begin{array}{l}50.50 \pm \\
27.75\end{array}$ & $\begin{array}{l}8.28 \pm \\
0.24\end{array}$ & $11.42 \pm 3.96$ & $\begin{array}{l}0.40 \pm \\
0.16\end{array}$ & $\begin{array}{l}1.91 \pm \\
0.78\end{array}$ & $\begin{array}{l}1.81 \pm \\
0.63\end{array}$ \\
\hline & $\begin{array}{l}\| A \\
20)\end{array}(n=$ & $\begin{array}{l}133.07 \pm \\
25.57\end{array}$ & $\begin{array}{l}59.58 \pm \\
7.66\end{array}$ & $\begin{array}{l}8.27 \pm \\
0.21\end{array}$ & $12.13 \pm 3.30$ & $\begin{array}{l}0.39 \pm \\
0.09\end{array}$ & $\begin{array}{l}1.76 \pm \\
0.48\end{array}$ & $\begin{array}{l}1.94 \pm \\
0.53\end{array}$ \\
\hline & $P$ value & 0.074 & 0.244 & 0.892 & 0.341 & 0.598 & 0.869 & 0.311 \\
\hline & $\begin{array}{l}\text { IB }(n= \\
14)\end{array}$ & $\begin{array}{l}135.62 \pm \\
40.58\end{array}$ & $\begin{array}{l}60.82 \pm \\
12.68\end{array}$ & $\begin{array}{l}8.28 \pm \\
0.36\end{array}$ & $13.76 \pm 5.68$ & $\begin{array}{l}0.59 \pm \\
0.29\end{array}$ & $\begin{array}{l}2.39 \pm \\
0.88\end{array}$ & $\begin{array}{l}2.16 \pm \\
0.79\end{array}$ \\
\hline & $\begin{array}{l}\text { IIB }(n= \\
27)\end{array}$ & $\begin{array}{l}100.54 \pm \\
25.97\end{array}$ & $\begin{array}{l}54.02 \pm \\
10.93\end{array}$ & $\begin{array}{l}8.09 \pm \\
0.16\end{array}$ & $8.70 \pm 2.55$ & $\begin{array}{l}0.29 \pm \\
0.08\end{array}$ & $\begin{array}{l}1.22 \pm \\
0.35\end{array}$ & $\begin{array}{l}1.33 \pm \\
0.39\end{array}$ \\
\hline & $P$ value & $0.001 *$ & $0.026^{*}$ & 0.067 & $0.002^{*}$ & 0.001 * & $\dot{0} 001 *$ & $<.001 *$ \\
\hline & $A U C$ & 0.82 & 0.71 & / & 0.79 & 0.81 & 0.90 & 0.85 \\
\hline
\end{tabular}

\section{Discussion}

The solitary inflammatory and cancer were two common kinds of lung lesions in the clinical practice. However, due to the similarity of their manifestations in conventional CT, the differentiation between them was difficult for radiologists. In our study, we investigated the potential of quantitative parameters derived from monochromatic images and material decomposition images (water-iodine) provided by gemstone 
spectral CT imaging in this field. As we all known, iodine was the main ingredient of contrast medium, which could directly reflect the blood flow and distribution in the intravascular and extracellular spaces of the tissue [18]. The spectral CT can provide both the monochromatic image series from 40 to $140 \mathrm{keV}$ and the material decomposition images. Multiple parameters could derive from spectral CT, such as iodine concentration, spectral curve, effective atomic number and CT value under different keV maps. The iodine concentration or normalized iodine concentration reflects the blood supply of the masses. Spectral curve reflected the dynamic change of measured CT numbers of ROls against increasing keV values. Each tissue had its characteristic HU curve. The slope is used to evaluate the attenuation characteristics in different tissues.

According to our analysis above, IC, NIC, $\lambda_{30}, \lambda_{40}$ under venous phase and $\lambda_{30}$ under arterial phase of general solitary inflammatory group were significantly higher than solitary lung cancer group, although their AUCs (Table.2) under the ROC curves were not high. The findings were partly consistent with some previous studies $[19,20]$ about the differences of NIC and $\lambda_{30}$ between inflammatory and cancer lesions. However, there were no significant differences between these two groups when using the parameters under the arterial phase expect $\lambda_{30}$. Some reasons could be used to explained this finding. Firstly, the injection flow rate used in our study was $3-3.5 \mathrm{ml} / \mathrm{s}$, while some previous studies $[17,19,20]$ set this value to $4-5 \mathrm{ml} / \mathrm{s}$ or even higher $6 \mathrm{ml} / \mathrm{s}$. Secondly, the timings for AP and VP were different. We applied the triggering technology in our study to minimize the impact of individual differences instead of the experienced values, and the VP was set $40 \mathrm{~s}$ delay after the AP. The scan timing may cause the finding differences among previous studies.

When we took the $D_{\max }$ into account, the study revealed some interesting results. In clinical, we usually classified lung lesions less than $3 \mathrm{~cm}$ in maximum diameter as nodules, and larger than $3 \mathrm{~cm}$ as masses. The inflammatory and cancer groups in our study were also classified into two subgroups respectively. No significant differences were found between the GSI parameters of group IA ( $D_{\max } \leq 3 \mathrm{~cm}$ ) and IB $\left(D_{\max }>3 \mathrm{~cm}\right)$ of the inflammatory under both AP and VP. Also, there was no significant correlation between $D_{\max }$ and any GSI parameters. Therefore, this may not only indicate that the value of GSI parameters will not change with the lesion size, but also the structure tends to be homogeneous in the solitary lung inflammatory lesion. Proliferation of inflammatory granulation tissue or residual of acute inflammation will form granulomatous inflammation and organizing pneumonia, and the rich and dilatate capillaries of masses are stimulated by inflammation gradually $[22,23]$. Our finding was in line with the growth characteristics of lung inflammatory.

For lung cancer group, significant differences were found between GSI parameters of group IIA and IIB under both $\mathrm{AP}$ and VP except parameter $\mathrm{HU}_{70 \mathrm{kev}}$ (Table 4). Significantly negative correlation between $D_{\max }$ and GSI parameters (except $\mathrm{HU}_{70 \mathrm{kev}}$ ) were also found. That was to say, the larger the cancer lesions were, the lower the GSI parameters were. This finding indicated that the structure of solitary lung cancer lesion tends to be inhomogeneous. This finding was in line with the lung malignant tumor growth characteristics. As we all know, malignant tumors tended to grow towards the blood vessels to find 
nutrition [24]. In malignant tumors, the establishment of angiogenesis and irregular vascular networks usually appeared, which could not support the rapid growth of tumor. Subsequently, the delivery of oxygen reduced, hypoxic in lung cancer occurred. With the continuous hypoxic, the necrosis might appear, which resulted in the tumor inhomogeneous.

The distinction between solitary lung inflammatory and cancer when the $D_{\max }$ were not lager than $3 \mathrm{~cm}$ confused radiologists much using the conventional CT in practice. In our study, $\mathrm{HU}_{40 \mathrm{kev}}$ and $\mathrm{HU}_{70 \mathrm{kev}}$ under AP of solitary cancer were significantly higher than those of solitary inflammatory when the $\mathrm{D}_{\max }$ was no larger than $3 \mathrm{~cm}$, and the sensitivity and specificity for $\mathrm{HU}_{40 \mathrm{kev}}$ and $\mathrm{HU}_{70 \mathrm{kev}}$ under $\mathrm{AP}$ were $95.0 \%$, $58.8 \%$ and $75.0 \%, 82.45 \%$ respectively. However, significant differences were not found in iodine concentration and the slope of spectral curve between above two groups, which indicated that the blood supplies of solitary lung inflammatory and cancer were close when the $D_{\max }$ were not lager than $3 \mathrm{~cm}$. Nevertheless, our finding showed that GSI parameter might be a new way to distinguish them despite our finding might be affected by several possible factors, such as the subject number, scanning protocol, injection flow rate etc.. When the $D_{\max }$ were lager than $3 \mathrm{~cm}$, the $\mathrm{HU}_{40 \mathrm{kev}}, \mathrm{IC}, \mathrm{NIC}, \lambda_{30}$ and $\lambda_{40}$ under both $A P$ and $V P, Z_{\text {eff }}$ under $A P$ and $H U_{70 \text { kev }}$ under VP of the inflammatory group were significantly higher than those of the cancer group. And the $\lambda_{30}$ under VP performed the best (AUC 0.90 , sensitivity $96.30 \%$ and specificity $85.71 \%)$.

This study also had some limitations. First, the number of subjects in subgroups was small. Further collection needs to be performed in the future. Second, we divided the groups using $3 \mathrm{~cm}$ as a $D_{\max }$ cutoff, more cutoffs should be used to reveal more findings about the differentiation, especially the characteristics of lesion when their $D_{\max }$ was between $2 \mathrm{~cm}$ and $3 \mathrm{~cm}$. We will do more research with a larger number of lesions in the future.

\section{Conclusions}

In conclusion, most of quantitative parameters of GSI can contribute to the differentiation between solitary lung cancer from solitary inflammatory lesions when $D_{\max }$ is larger than $3 \mathrm{~cm}$, while only few parameters are meaningful when $D_{\max }$ is smaller than $3 \mathrm{~cm}$.

\section{Abbreviations}

GSI, gemstone spectral imaging; $C T$, computed tomography; $Z_{\text {eff }}$ effective atomic number; IC, iodine concentration; NIC, normalized IC; AP, arterial phase; VP, venous phase; $\mathrm{HU}_{40 \mathrm{kev}}$, the $\mathrm{CT}$ number on the 40kev monochromatic image; $\mathrm{HU}_{70 \mathrm{kev}}$, the $\mathrm{CT}$ number on the 70kev monochromatic image; $\lambda_{30}, \mathrm{HU}_{40 \mathrm{keV}^{-}}$ $\mathrm{HU}_{70 \mathrm{keV}} / / 30 ; \lambda_{40}, \mid \mathrm{HU}_{40 \mathrm{keV}}-\mathrm{HU}_{80 \mathrm{keV}} \mathrm{V} / 40 ; \mathrm{CTDI}_{\mathrm{vol}}, \mathrm{CT}$ dose index volume; ROI, region of interest; ROC, receiver operating characteristic curve; NSCLC, non-small cell lung cancer; SPN, solitary pulmonary nodule. 


\section{Declarations}

\section{Ethics approval and consent to participate}

This study was approved by the academic committee at The Second Affiliated Hospital of Xiamen Medical College and written informed consent has been obtained from each patient.

\section{Consent for publication}

Not applicable.

\section{Availability of data and materials}

Materials are available upon request.

\section{Competing interests}

All authors declared that they had no conflicts of interest to disclose.

\section{Funding}

The research is partially supported by Planning Project Grand (3502Z20174012) and Guiding Project Grand (3502Z20199040) from Xiamen Municipal Bureau of Science and Technology (CN).

\section{Authors' contributions}

Liuhong Zhu, Funan Wang: conceptualization, methodology, data acquisition, data analysis and interpretation, writing original draft preparation; Yanwei Wang: data curation, visualization, investigation; Jianjun Zhou and Qihua Cheng: Study supervision, review and revision of manuscript. All authors read and approved the final manuscript.

\section{Acknowledges}

The authors thank Prof. Gang Guo from the Second Affiliated Hospital of Xiamen Medical College for help in this study.

\section{References}

1. Cao M, Chen W. Epidemiology of lung cancer in China. Thorac Cancer. 2019;10(1):3-7.

2. Bray F, Ferlay J, Soerjomataram I, Siegel RL, Torre LA, Jemal A. Global cancer statistics 2018 : GLOBOCAN estimates of incidence and mortality worldwide for 36 cancers in 185 countries. CA: A Cancer Journal for Clinicians. 2018; 68(6): 394-424.

3. Martín-Sánchez J, Carlos, Nuno L, González-Marrón Adrián L-M, Cristina, Nuria MS, Ramon C, et al. Projections in Breast and Lung Cancer Mortality among Women: A Bayesian Analysis of 52 
Countries Worldwide. Cancer Res. 2018;78:4436-42.

4. Wang G, Zhang C, Li M, Deng K, Li W. Preliminary application of high-definition computed tomographic Gemstone Spectral Imaging in lung cancer. J Comput Assist Tomogr. 2014;38(1):7781.

5. Kim H, Goo JM, Kang CK, Chae KJ, Park CM. Comparison of lodine Density Measurement Among Dual-Energy Computed Tomography Scanners From 3 Vendors. Invest Radiol. 2018;53(6):321-7.

6. Zhang D, Li X, Liu B. Objective characterization of GE discovery CT750 HD scanner: gemstone spectral imaging mode. Med Phys. 2011;38:1178-88.

7. Wu HW, Cheng JJ, Li JY. Pulmonary embolism detection and characterization through quantitative iodine-based material decomposition images with spectral computed tomography imaging. Invest Radiol. 2012;47:85-91.

8. Liu G, Li M, Li G, Li Z, Liu A, Pu R, et al. Assessing the blood supply status of the focal ground-glass opacity in lungs using spectral computed tomography. Korean Journal of Radiology. 2018;19(1):130-8.

9. Zhang Y, Tang J, Xu J, Cheng J, Wu H. Analysis of pulmonary pure ground-glass nodule in enhanced dual energy CT imaging for predicting invasive adenocancer: Comparing with conventional thinsection CT imaging. Journal of thoracic Disease. 2017;9(12):4967-78.

10. Fehrenbach U, Kahn J, Böning G, Feldhaus F, Merz K, Frost N, et al. Spectral CT and its specific values in the staging of patients with non-small cell lung cancer: technical possibilities and clinical impact. Clin Radiol. 2019;74(6):456-66.

11. Chen XH, Ren K, Liang P, Chai YR, Chen KS, Gao JB. Spectral computed tomography in advanced gastric cancer: Can iodine concentration non-invasively assess angiogenesis? World J Gastroenterol. 2017;23(9):1666-75.

12. Meng X, Ni C, Shen Y, Hu X, Chen X, Li Z, et al. Differentiating malignant from benign gastric mucosal lesions with quantitative analysis in dual energy spectral computed tomography. Medicine. 2017;96(2):e5878.

13. Zeng YR, Yang QH, Liu QY, Min J, Li HG, Liu ZF, et al. Dual energy computed tomography for detection of metastatic lymph nodes in patients with hepatocellular cancer. World J Gastroenterol. 2019;25(16):1986-96.

14. Pfeiffer D, Parakh A, Patino M, Kambadakone A, Rummeny E, Sahani D. Iodine material density images in dual-energy CT: quantification of contrast uptake and washout in HCC. Abdominal Radiology (NY). 2018;43(12):3317-23.

15. Yang CB, Zhang S, Jia YJ, Yu Y, Duan HF, Zhang XR, et al. Dual energy spectral CT imaging for the evaluation of small hepatocellular cancer microvascular invasion. Eur J Radiol. 2017;95:222-7.

16. Yang F, Dong J, Wang X, Fu X, Zhang T. Non-small cell lung cancer: Spectral computed tomography quantitative parameters for preoperative diagnosis of metastatic lymph nodes. Eur J Radiol. 2017;89:129-35. 
17. Chen ML, Li XT, Wei YY, Qi LP, Sun YS. Can spectral computed tomography imaging improve the differentiation between malignant and benign pulmonary lesions manifesting as solitary pure ground glass, mixed ground glass, and solid nodules? Thorac Cancer. 2019;10(2):234-42.

18. Chae EJ, Song JW, Seo JB, Krauss B, Jang YM, Song KS. Clinical utility of dual-energy CT in the evaluation of solitary pulmonary nodules: initial experience. Radiology. 2008;249(2):671-81.

19. Hou W, Wu HW, YinY, Cheng JJ, Zhang Q, Xu JR. Differentiation of Lung Cancers From Inflammatory Masses with Dual-Energy Spectral CT Imaging. Academic Radiology. 2015;22(3):337-44.

20. Wu F, Zhou H, Li F, Wang JT, Ai T. Spectral CT Imaging of Lung Cancer: Quantitative Analysis of Spectral Parameters and Their Correlation with Tumor Characteristics. Acad Radiol. 2018;25(11):1398-404.

21. Li M, Zhang L, Tang W, Jin YJ, Qi LL, Wu N. Identification of epidermal growth factor receptor mutations in pulmonary adenocancer using dual-energy spectral computed tomography. Eur Radiol. 2019;29(6):989-2997.

22. Feinstein MB, DeSouza SA, Moreira AL, Stover DE, Heelan RT, Lyriboz TA, et al. A comparison of the pathological, clinical and radiographical, features of cryptogenic organising pneumonia, acute fibrinous and organising pneumonia and granulomatous organising pneumonia. J Clin Pathol. 2015;68:441-7.

23. Huo Z, Feng R, Tian X, Zhang H, Huo L, Liu H. Clinicopathological findings of focal organizing pneumonia: A retrospective study of 37 cases. Int J Clin Exp Pathol. 2015;8(1):511-6.

24. Wu PH, Giri A, Sun SX, Wirtz D. Three-dimensional cell migration does not follow a random walk. PNAS. 2014;111(11):3949-54.

\section{Figures}




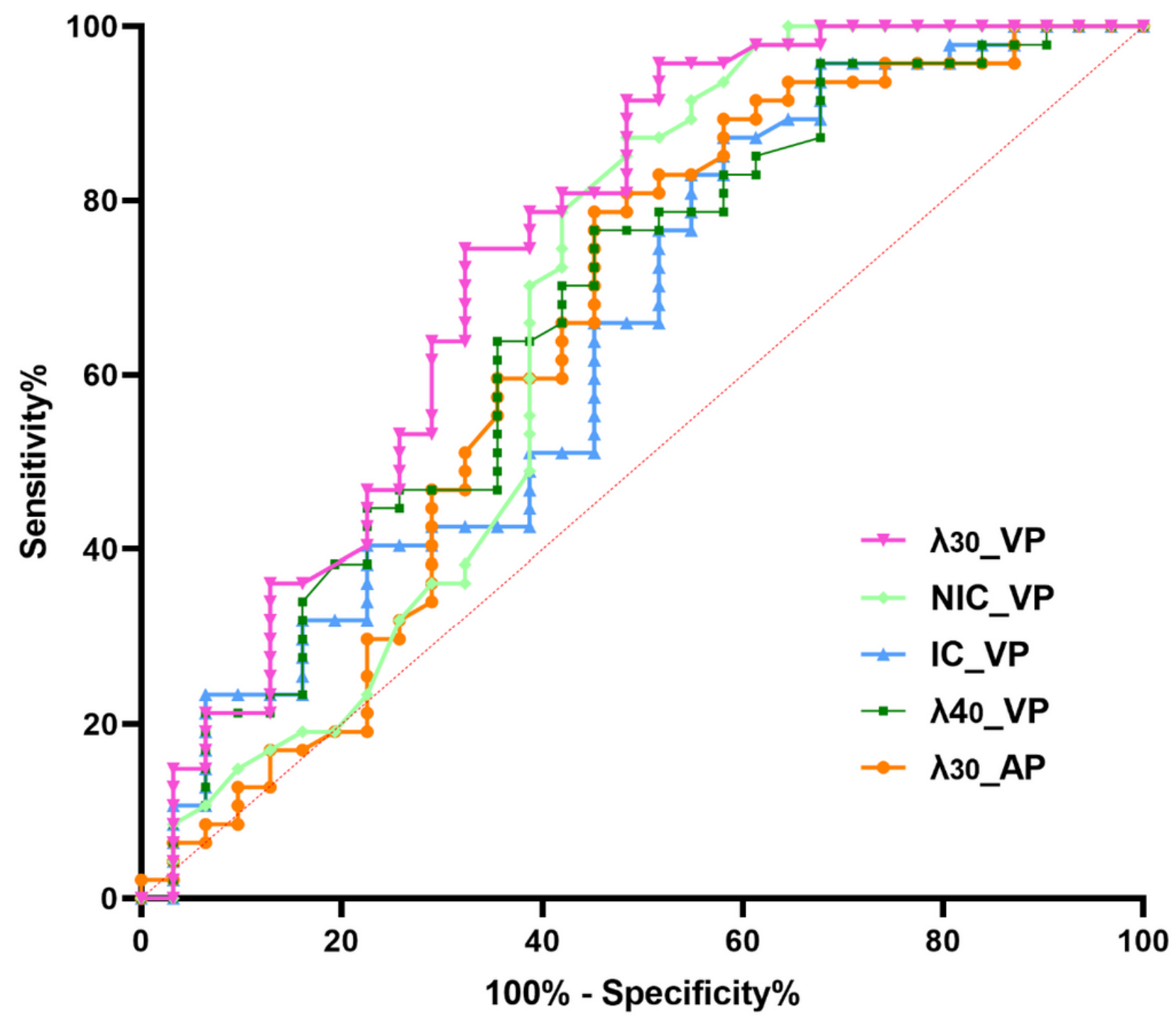

Figure 1

Receive operating characteristic (ROC) curves by using IC, NIC, $\lambda 30, \lambda 40$ under VP and $\lambda 30$ under AP to differentiate solitary inflammatory from cancer. 


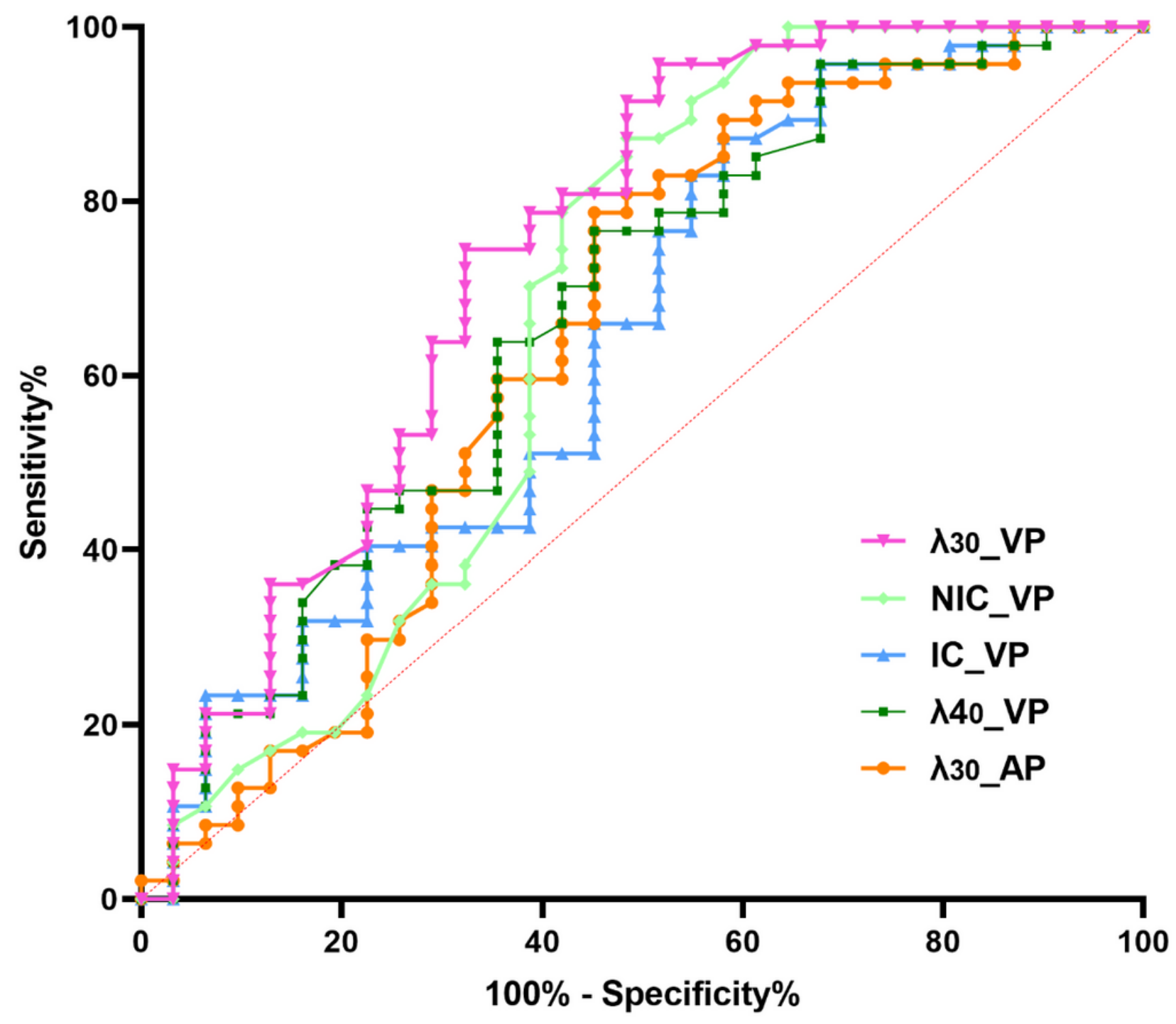

Figure 1

Receive operating characteristic (ROC) curves by using IC, NIC, $\lambda 30, \lambda 40$ under VP and $\lambda 30$ under AP to differentiate solitary inflammatory from cancer. 

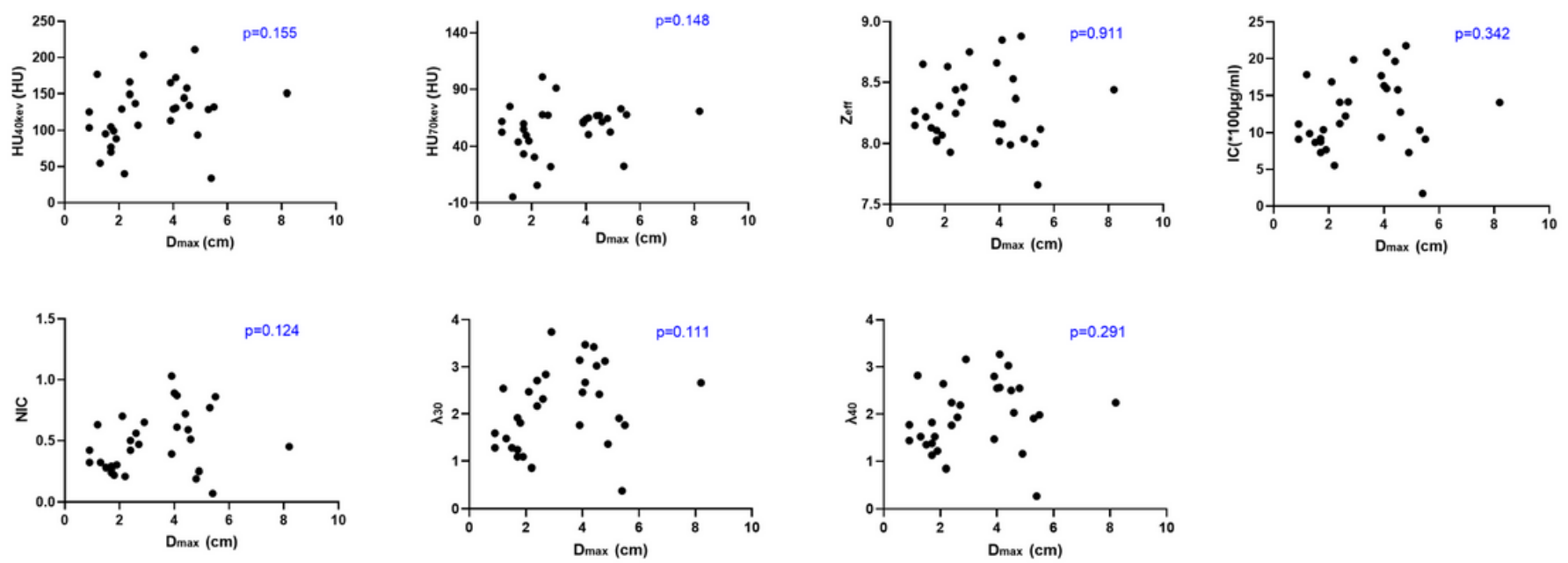

\section{Figure 2}

The scatter chart of GSI parameters of the solitary inflammatory group changed with Dmax under VP. Analysis about Pearson linThe scatter chart of GSI parameters of the solitary inflammatory group changed with Dmax under VP. Analysis about Pearson linear correlation between Dmax and GSI parameters were done. And $p$ values of all parameters were larger than 0.05 , which means the GSI parameters under VP of the solitary inflammatory group will not change with Dmax.ear correlation between Dmax and GSI parameters were done. And $p$ values of all parameters were larger than 0.05 , which means the GSI parameters under VP of the solitary inflammatory group will not change with Dmax.
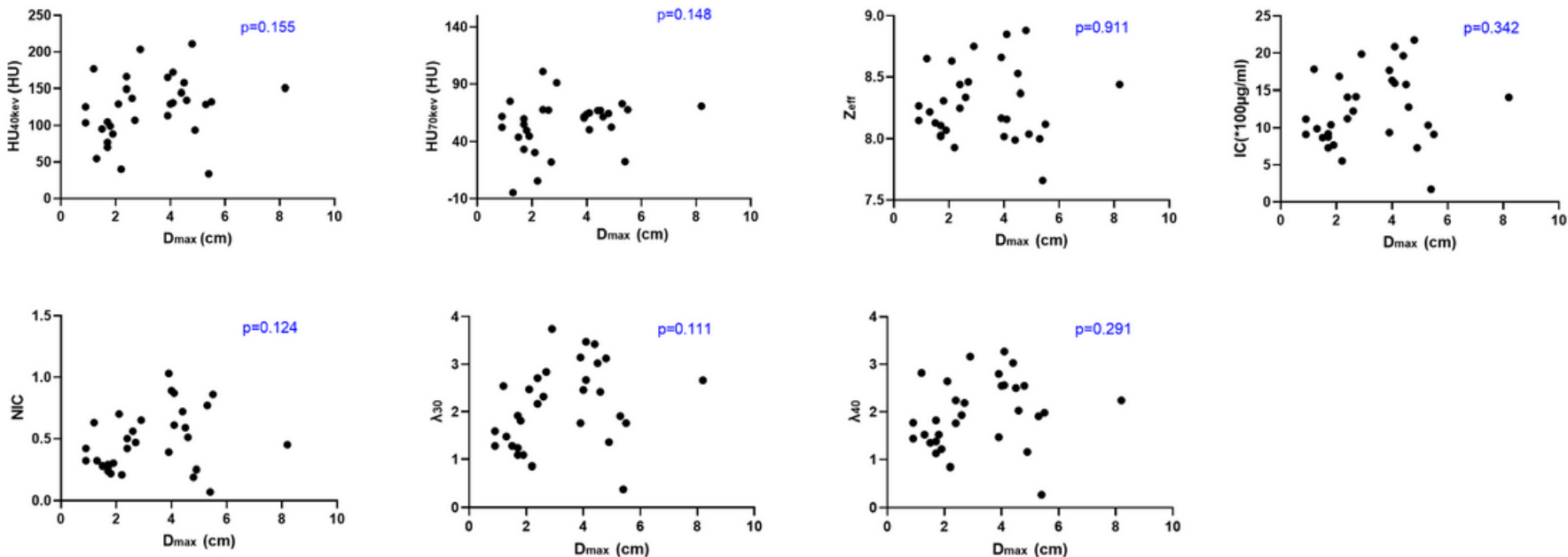

\section{Figure 2}

The scatter chart of GSI parameters of the solitary inflammatory group changed with Dmax under VP. Analysis about Pearson linThe scatter chart of GSI parameters of the solitary inflammatory group 
changed with Dmax under VP. Analysis about Pearson linear correlation between Dmax and GSI parameters were done. And $p$ values of all parameters were larger than 0.05 , which means the GSI parameters under VP of the solitary inflammatory group will not change with Dmax.ear correlation between Dmax and GSI parameters were done. And $p$ values of all parameters were larger than 0.05 , which means the GSI parameters under VP of the solitary inflammatory group will not change with Dmax.
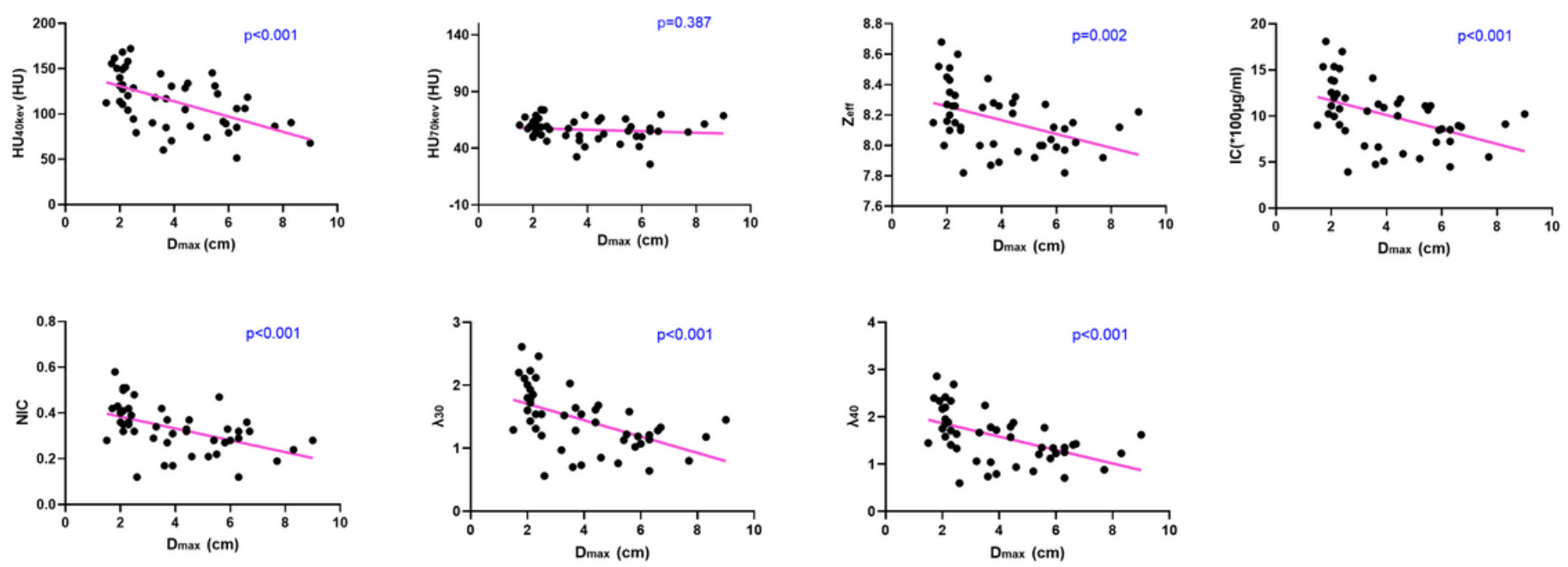

\section{Figure 3}

The scatter chart of GSI parameters of the solitary lung cancer group changed with Dmax under VP. Analysis about Pearson linear correlation between Dmax and GSI parameters were also done. All the parameters except HU70kev had significantly negative correlation with Dmax, which meant that the larger Dmax was, the smaller GSI parameters will be.
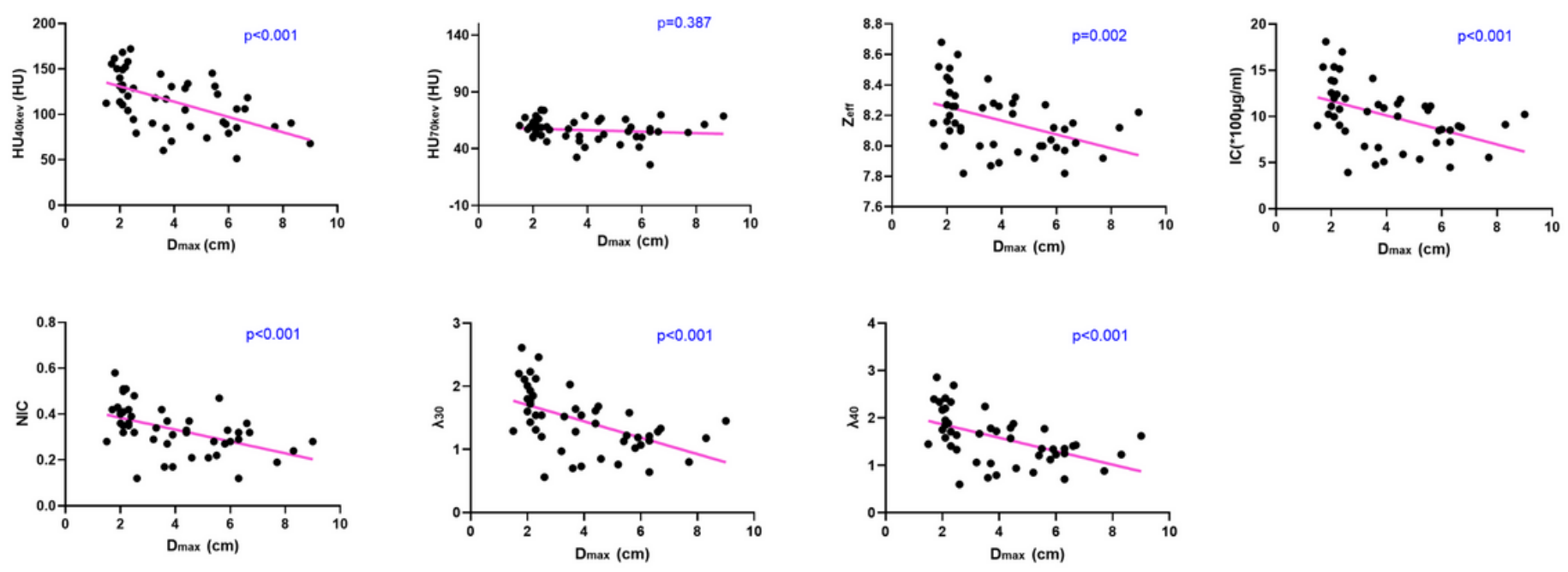

Figure 3 
The scatter chart of GSI parameters of the solitary lung cancer group changed with Dmax under VP. Analysis about Pearson linear correlation between Dmax and GSI parameters were also done. All the parameters except HU70kev had significantly negative correlation with Dmax, which meant that the larger Dmax was, the smaller GSI parameters will be.
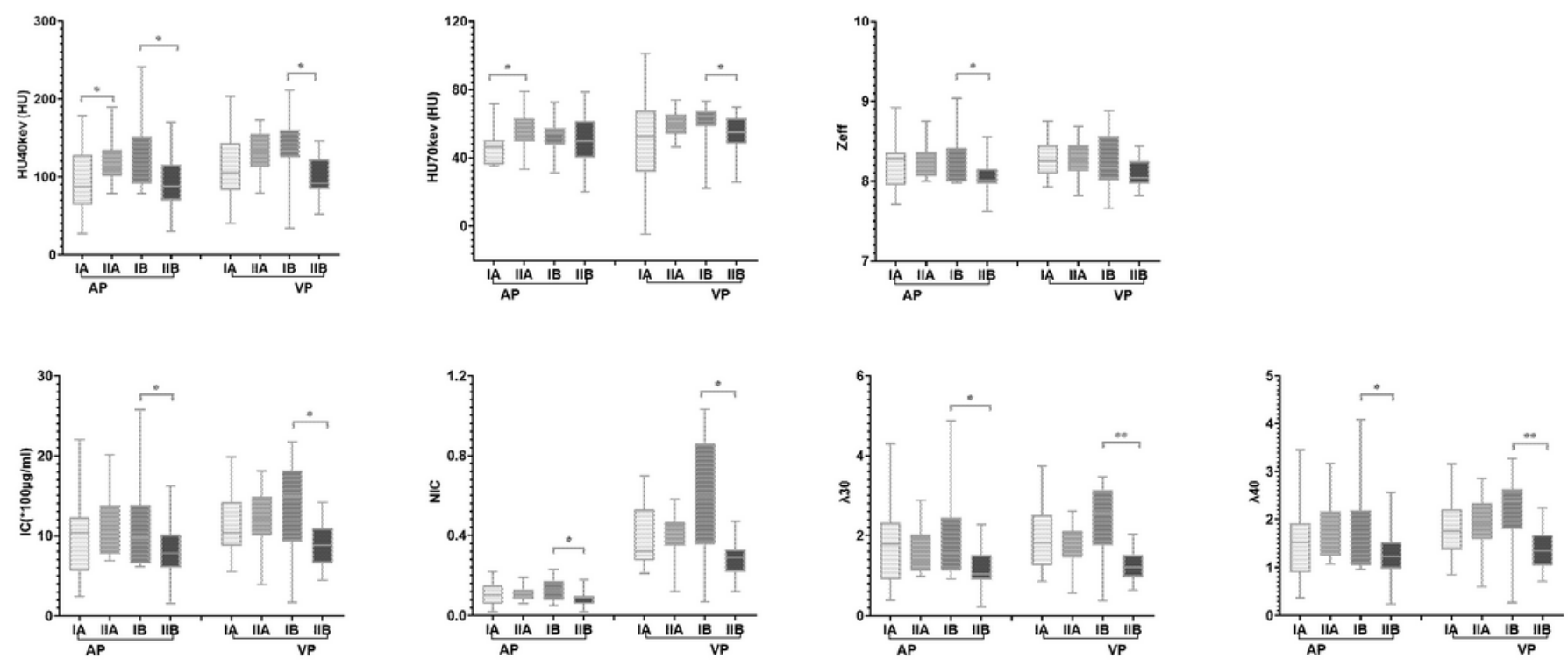

\section{Figure 4}

The box-whisker plots for comparisons of GSI parameters of four subgroups under both AP and VP (* means $0.001<p<0.05$, **means $p<0.001$ ).
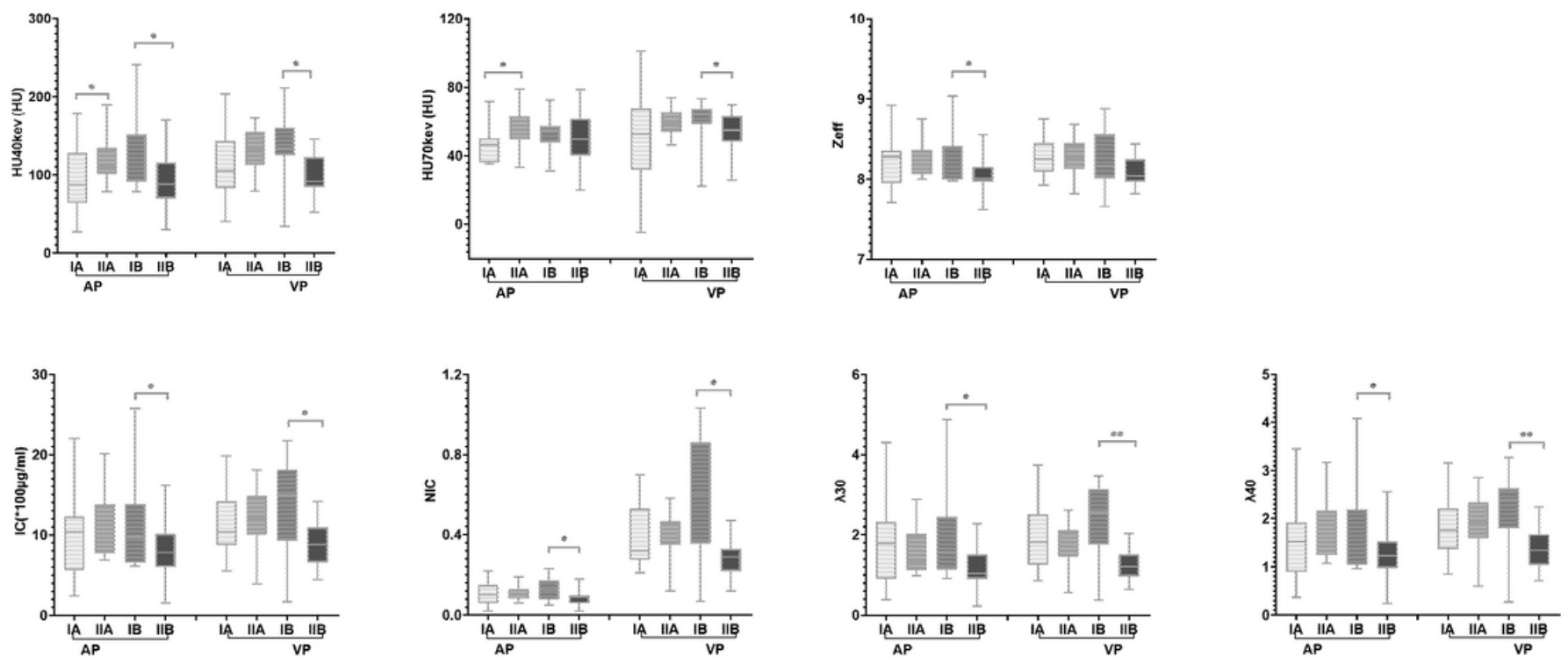

Figure 4 
The box-whisker plots for comparisons of GSI parameters of four subgroups under both AP and VP (* means $0.001<p<0.05$, **means $p<0.001$ ).
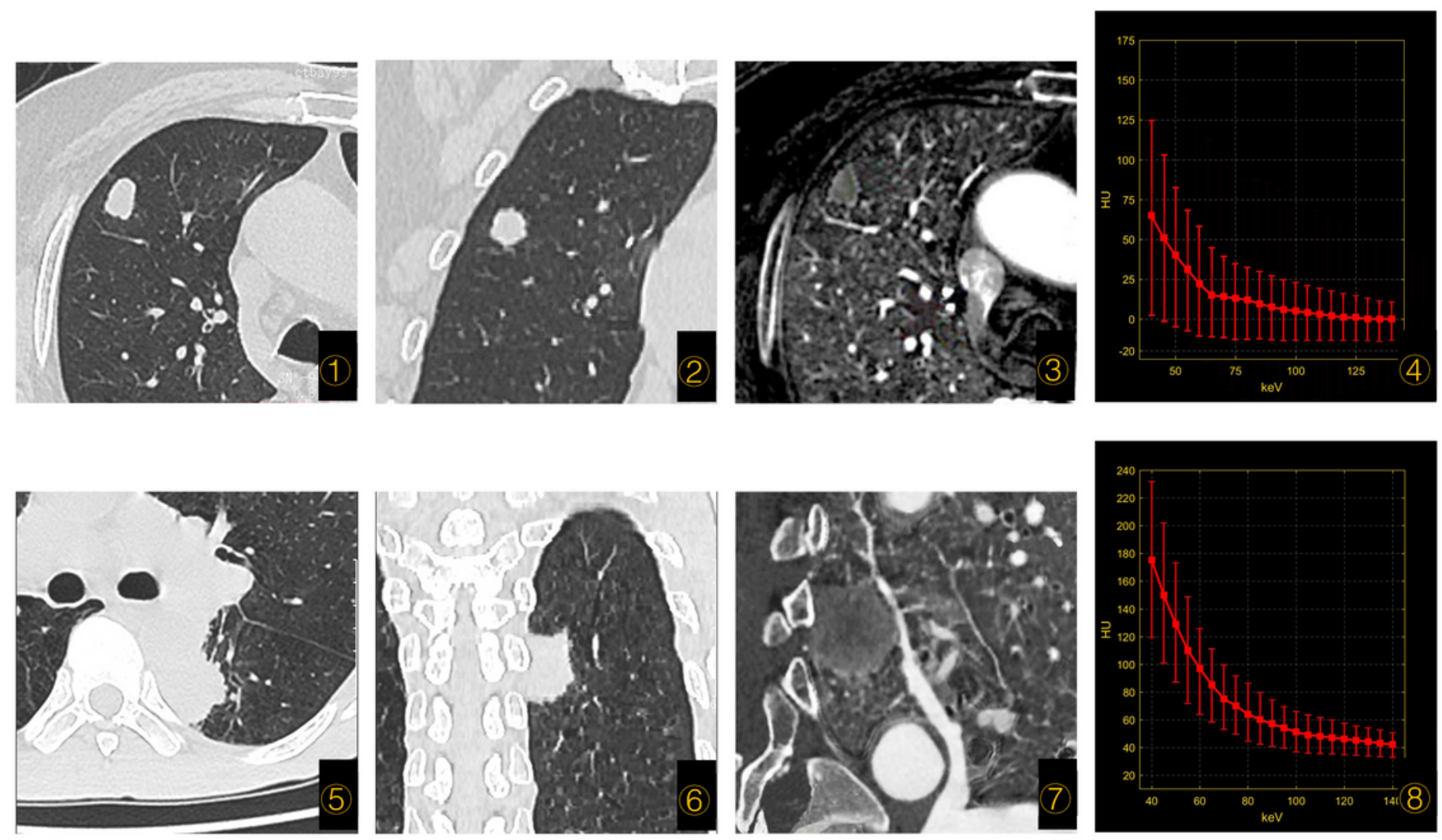

\section{Figure 5}

Lung CT Images of inflammatory and cancer lesions with Dmax less than $3 \mathrm{~cm}$. Plain and spectral CT images under AP from a 74-year-old male with pneumonia ( $\mathbb{X}-\mathbb{Z}, \mathrm{Dmax}=1.5 \mathrm{~cm}$ ) which was misdiagnosed

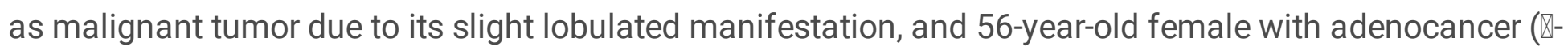

$\bigotimes, D$ max $=3.4 \mathrm{~cm})$ : axial and coronal or CPR images with pulmonary window ( $(\mathrm{Q}, \mathrm{Q}, \mathrm{Q})$, iodine-based images

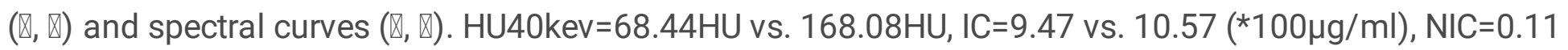
vs. $0.13, \lambda 30=1.85$ vs. 2.12 . 

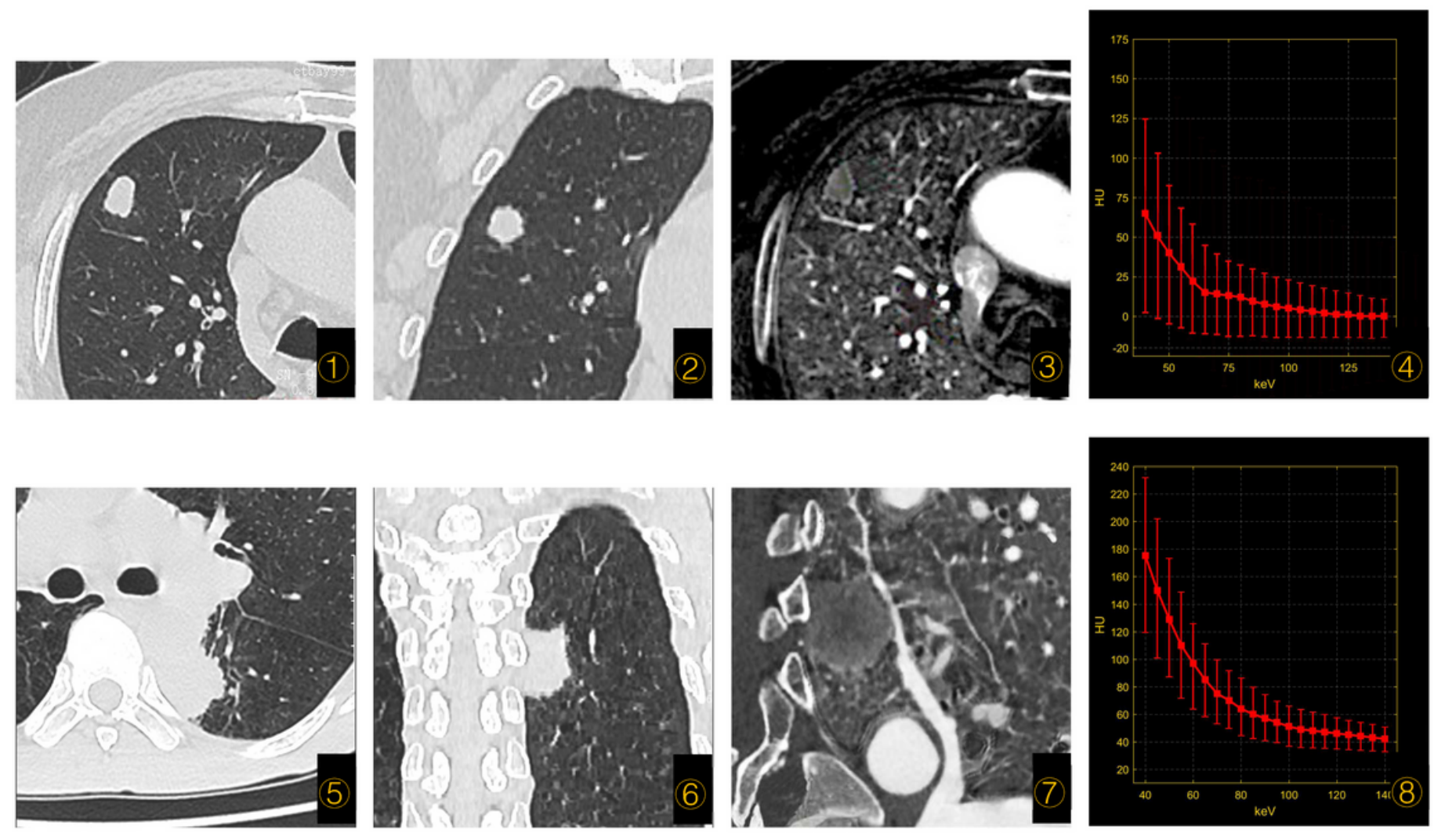

Figure 5

Lung CT Images of inflammatory and cancer lesions with Dmax less than $3 \mathrm{~cm}$. Plain and spectral CT images under AP from a 74-year-old male with pneumonia ( $(-\mathbb{X}, \mathrm{Dmax}=1.5 \mathrm{~cm})$ which was misdiagnosed

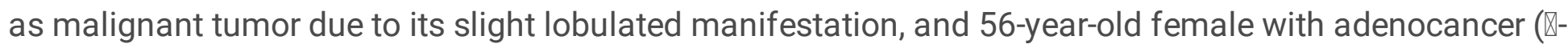

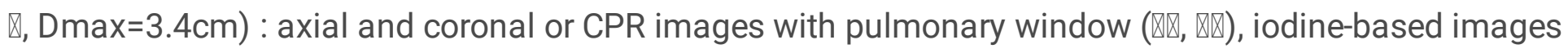

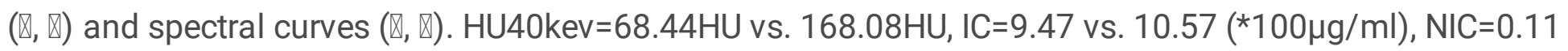
vs. $0.13, \lambda 30=1.85$ vs. 2.12 . 

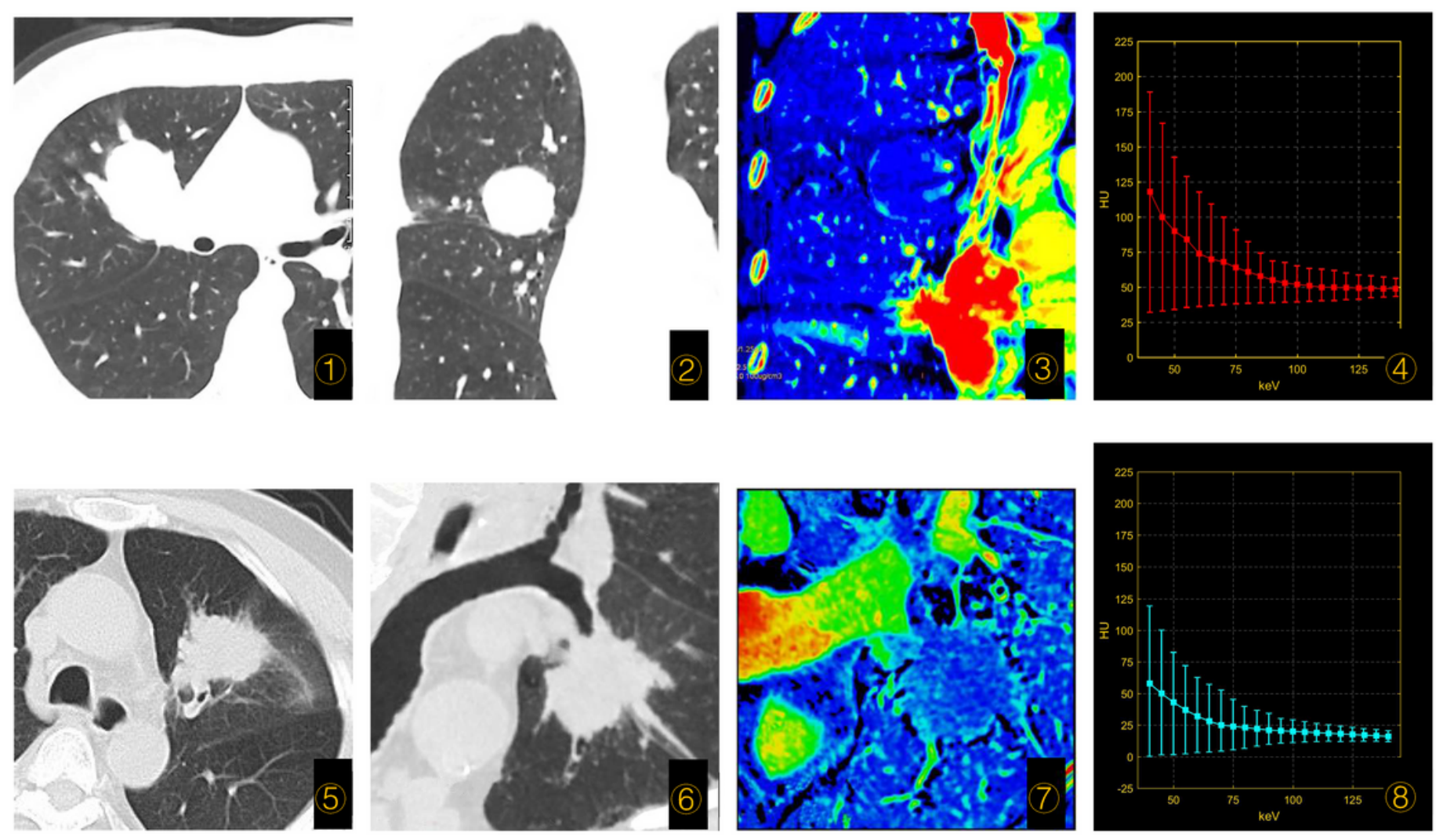

Figure 6

Lung CT Images of inflammatory and cancer lesions with Dmax lager than $3 \mathrm{~cm}$. Plain and spectral CT images under AP from a 35-year-old female suffering from inflammatory granuloma with local fibrosis ( $\mathbb{X}$ -

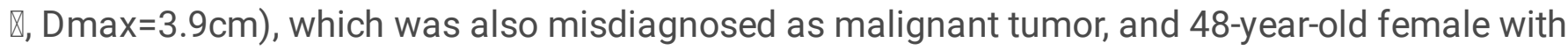
adenocancer $(\mathbb{X}-\mathbb{Z}, \mathrm{Dmax}=3.4 \mathrm{~cm})$ : axial and coronal or curved planar reconstruction $(\mathrm{CPR})$ images with

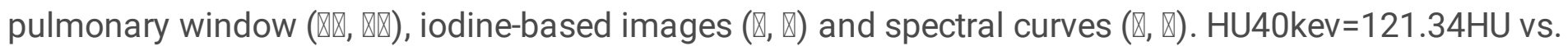
$59.25 \mathrm{HU}, \mathrm{IC}=17.67$ vs. $4.75\left({ }^{*} 100 \mu \mathrm{g} / \mathrm{ml}\right), \mathrm{NIC}=1.03$ vs. $0.17, \lambda 30=3.14$ vs. 0.75 , and $\lambda 40=2.80$ vs. 0.74 . 

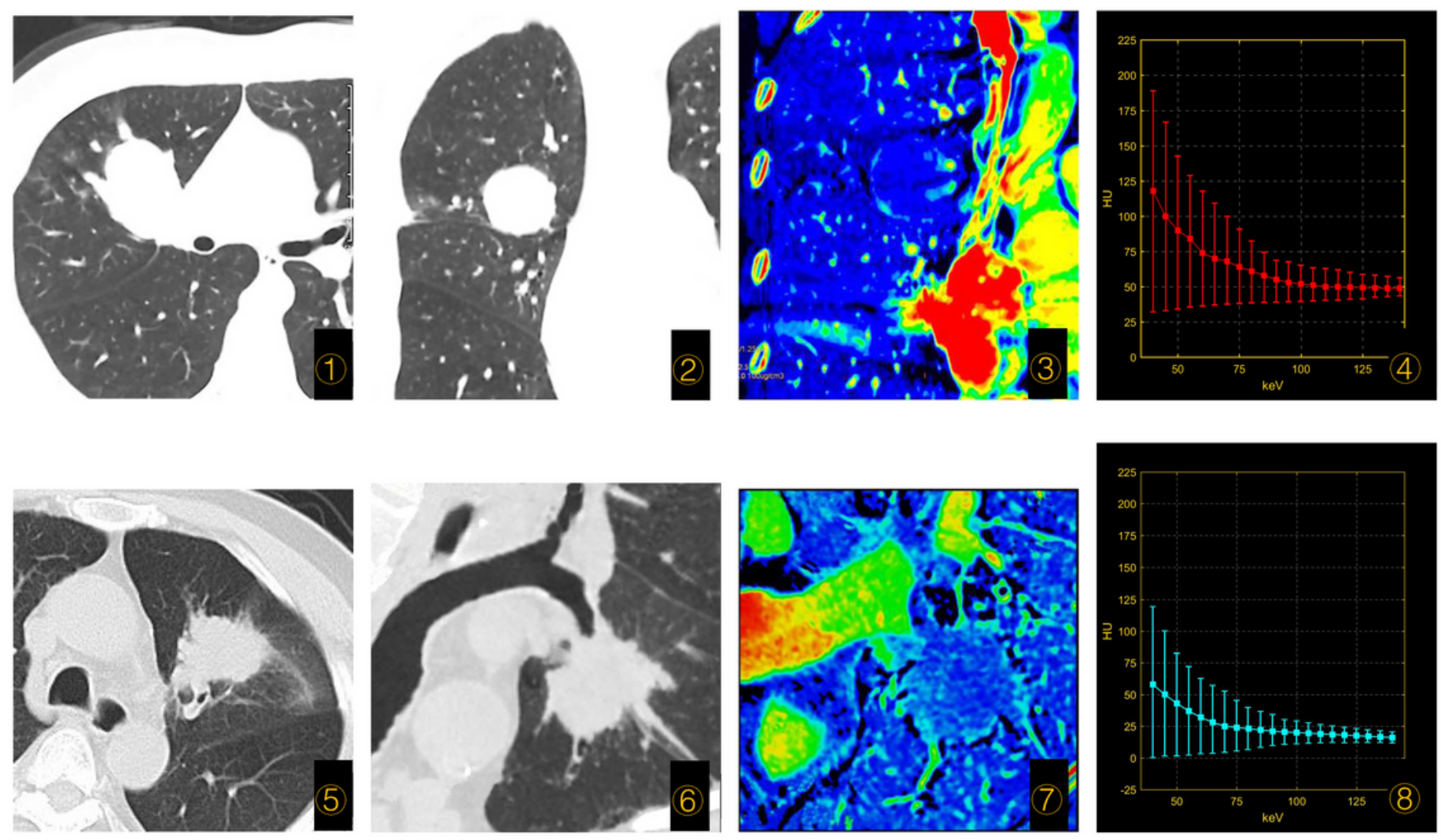

\section{Figure 6}

Lung CT Images of inflammatory and cancer lesions with Dmax lager than $3 \mathrm{~cm}$. Plain and spectral CT images under AP from a 35-year-old female suffering from inflammatory granuloma with local fibrosis ( $\mathbb{X}$ -

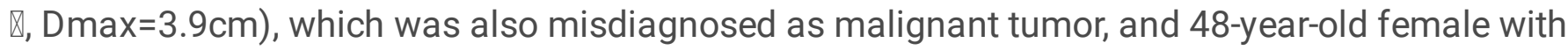
adenocancer $(\mathbb{X}-\mathbb{Z}, \mathrm{Dmax}=3.4 \mathrm{~cm})$ : axial and coronal or curved planar reconstruction (CPR) images with

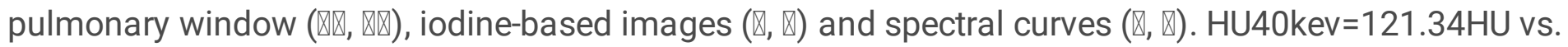
$59.25 \mathrm{HU}, \mathrm{IC}=17.67$ vs. $4.75\left({ }^{*} 100 \mu \mathrm{g} / \mathrm{ml}\right), \mathrm{NIC}=1.03$ vs. $0.17, \lambda 30=3.14$ vs. 0.75 , and $\lambda 40=2.80$ vs. 0.74 . 


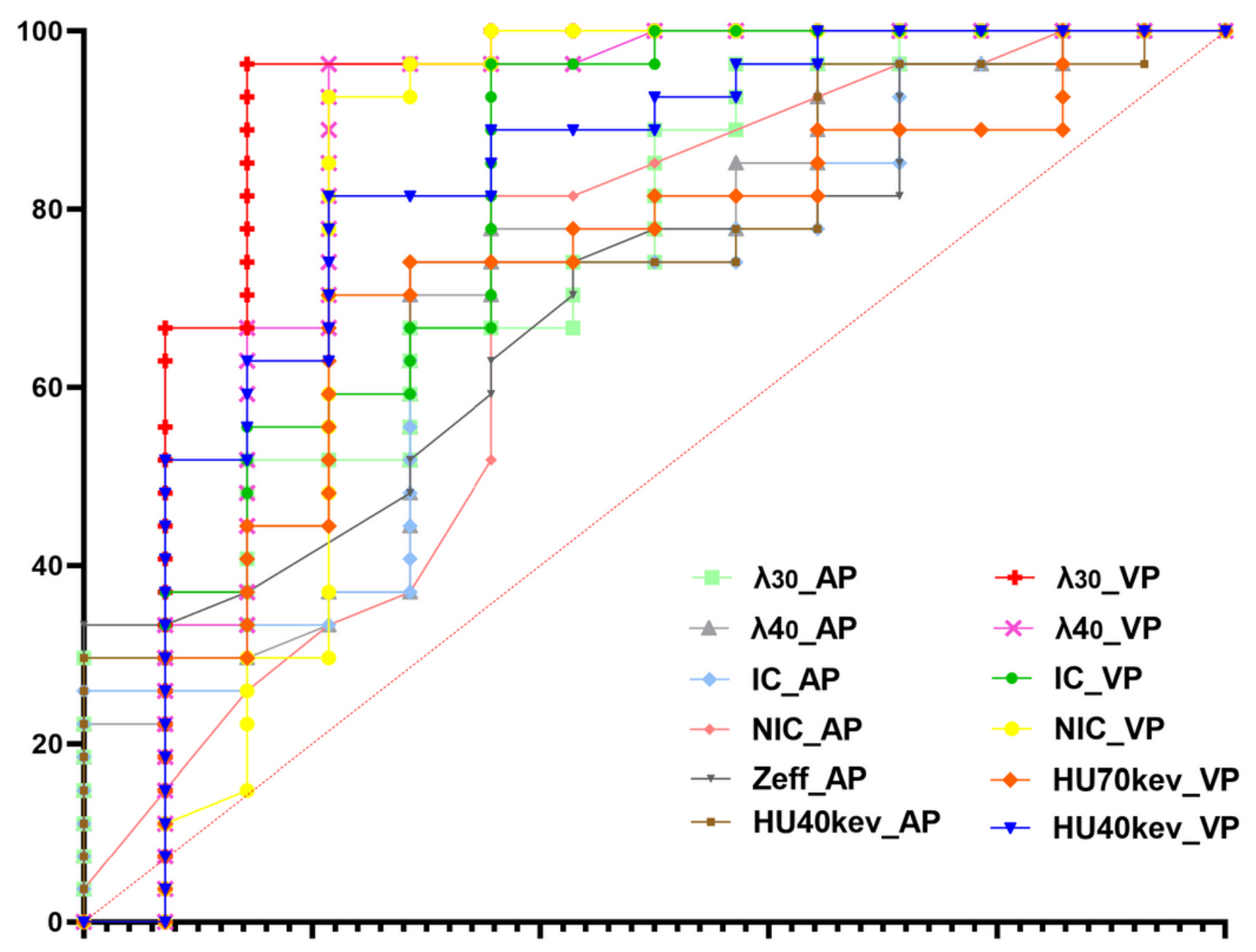

Figure 7

Receive operating characteristic (ROC) curves by using HU40kev, IC, NIC, $\lambda 30, \lambda 40$ under both AP and VP, Zeff under AP and HU70kev under VP to differentiate solitary inflammatory from cancer when Dmax lager than $3 \mathrm{~cm}$. The AUC for $\lambda 30$ under VP was largest, and the corresponding sensitivity and specificity were $96.32 \%$ and $85.71 \%$ respectively. 


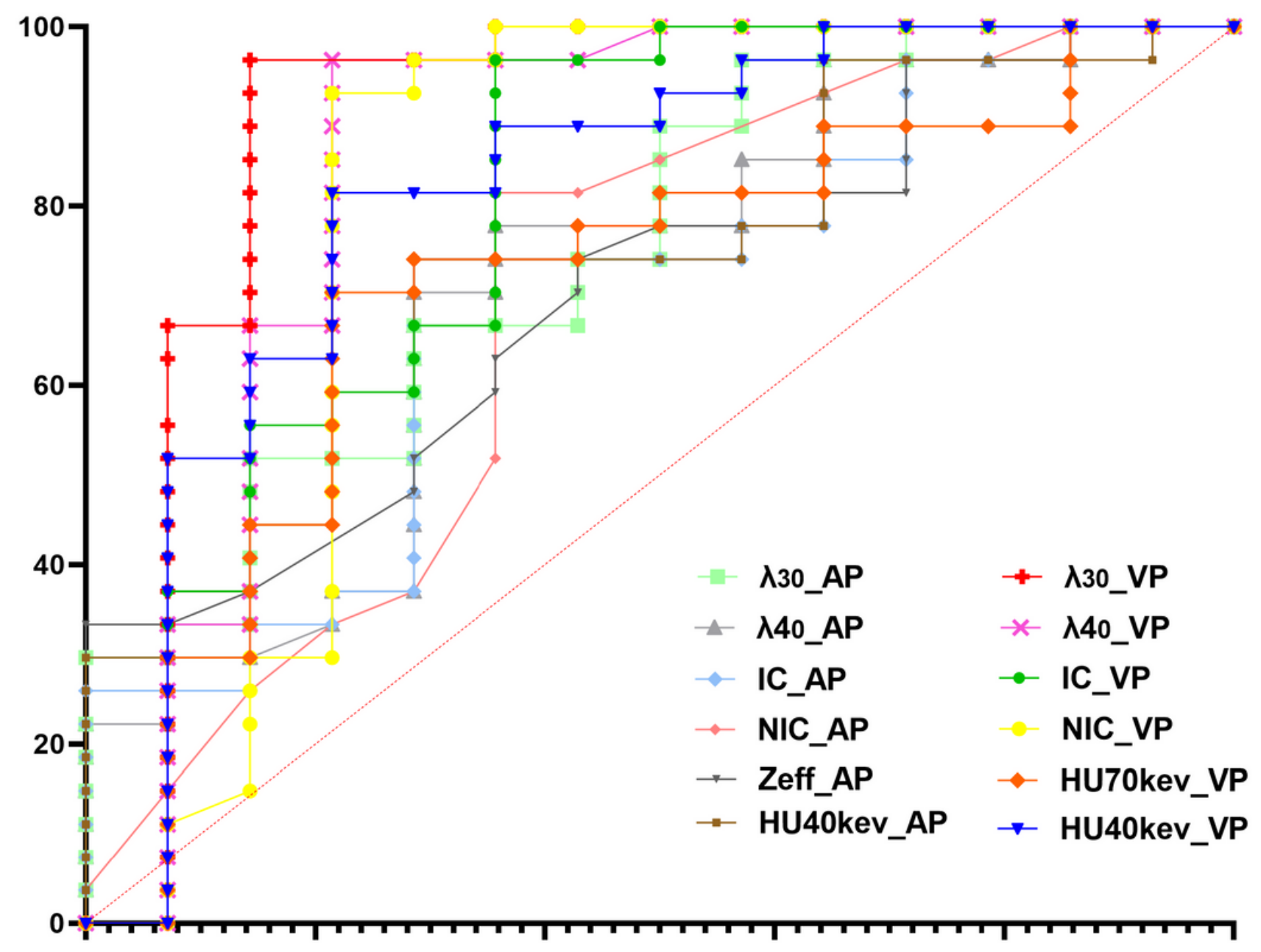

Figure 7

Receive operating characteristic (ROC) curves by using HU40kev, IC, NIC, $\lambda 30, \lambda 40$ under both AP and VP, Zeff under AP and HU70kev under VP to differentiate solitary inflammatory from cancer when Dmax lager than $3 \mathrm{~cm}$. The AUC for $\lambda 30$ under VP was largest, and the corresponding sensitivity and specificity were $96.32 \%$ and $85.71 \%$ respectively. 